\title{
Trabalhando em saúde pública pelo interior do Brasil: lembranças de uma geração de sanitaristas (1930-1970)
}

Working in public health in the Brazilian hinterland: memories of a generation of sanitarians (1930-1970)

\begin{abstract}
In this work we introduce some small pieces of interviews made with physicians who had acted in diverse Brazilian institutions of public health, mainly in the period between 1930-1970. In these interviews we can find the descriptions of different forms of control and combat of a number of illnesses, the organizational formats of the existing institutions, and the conceptions that guided those professionals. The stories highlight in particular the presence of those professionals in different regions of the country.
\end{abstract}

Key words History; Public Health; Sanitarians
Resumo O texto apresenta pequenos trechos de entrevistas realizadas com médicos sanitaristas que atuaram em diversas instituições de saúde pública, principalmente no período compreendido entre 1930-1970. Os depoimentos descrevem formas de controle e combate a determinadas doenças, o formato de organização institucional existente e as concepções que orientavam a atuação profissional. Destaca-se em particular os relatos que descrevem a presença destes profissionais em diferentes regiões do país.

Palavras-chave História; Saúde Pública; Sanitaristas
1 Casa de Oswaldo Cruz, Fundação Oswaldo Cruz. av. Brasil 4.365 Manguinhos, 21045-900 Rio de Janeiro, RJ fonseca@fiocruz.br 
O mundo dos velhos, de todos os velhos, é, de modo mais ou menos intenso, o mundo da memória. Dizemos: afinal, somos aquilo que pensamos, amamos, realizamos. E eu acrescentaria: somos aquilo que lembramos. Além dos afetos que alimentamos, a nossa riqueza são os pensamentos que pensamos, as ações que cumprimos, as lembranças que conservamos e não deixamos apagar e das quais somos o único guardião. (...) No entanto, as recordações não aflorarão se não as formos procurar nos recantos mais distantes da memória. O relembrar é uma atividade mental que não exercitamos com freqüência porque é desgastante ou embaraçosa. Mas é uma atividade salutar. Na rememoração reencontramos a nós mesmos e a nossa identidade, não obstante os muitos anos transcorridos, os mil fatos vividos (Bobbio:1997).

\section{Introdução}

Há alguns anos, ao coordenar um grupo de pesquisa sobre a Memória da Saúde Pública Brasileira contei com a oportunidade de iniciar um conjunto de entrevistas, com médicos sanitaristas brasileiros que se graduaram e iniciaram suas atividades profissionais ao longo da década de $1930 .^{1}$

Nosso objetivo inicialmente era o de recuperar a história do processo de institucionalização da saúde pública, que a partir do primeiro governo Vargas havia sofrido importantes transformações, como também por outro lado, identificar as concepções sobre saúde que embasavam tanto o processo de formação profissional, como a organização institucional do setor.

Minha intenção aqui é a de realizar um primeiro esforço para permitir que pequenos fragmentos destas lembranças se tornem públicas, possibilitando que o trabalho desenvolvido por estes profissionais em diferentes instituições de saúde e em diferentes regiões do país seja conhecido, mesmo que parcialmente. Portanto as reflexões que serão apresentadas, acompanhadas de fragmentos de algumas destas entrevistas, não se configuram como um trabalho de análise exaustiva sobre a história da saúde pública brasileira ou sobre o pensamento social de uma geração específica de médicos sanitaristas.

No contexto desta publicação que procura formalizar o debate sobre a trajetória da saúde pública no Brasil nos últimos cem anos, estes relatos são uma contribuição para as discussões e investigações acerca do formato político-institucional, que a área da saúde pública apresenta atualmente no Brasil.

Apesar do recorte cronológico inevitável pois dizem respeito principalmente às atividades desenvolvidas no período compreendido entre 1930-1970, fase de intensa atuação profissional do grupo - os depoimentos trazem informações sobre a saúde pública que, sem dúvida, remetem ao período anterior a 1930, do qual herdou-se parte da estrutura institucional que será reformulada, assim como concepções, idéias e problemas. Auxiliam também na compreensão do período posterior a 1970 e nos desdobramentos subseqüentes das políticas públicas de saúde.

Agrega-se ao objetivo do trabalho minha intenção de que ele represente uma forma de homenagem, através destes atores, a todos aqueles que se dedicaram durante tantos anos à saúde pública brasileira e hoje são em grande parte anônimos, para a maioria dos jovens profissionais das áreas de ciências humanas e saúde no Brasil. ${ }^{2}$

As transformações políticas que ocorreram no país a partir da revolução de 1930 tiveram reflexos imediatos no âmbito da saúde com a criação do Ministério da Educação e Saúde ainda no final daquele ano. Durante os anos seguintes, ao longo do governo provisório, a instabilidade política levou três ministros a ocuparem o ministério, o que dificultou a elaboração e implementação de uma política efetiva para o setor.

Será a partir de 1934, com a posse de Gustavo Capanema como ministro da educação e saúde, que terá inicio o processo de elaboração e aprovação de um projeto de reforma para a área da saúde pública. Implementada em 1937, esta reforma definiu importantes mudanças na área, tendo à frente o dr. João de Barros Barreto, nomeado diretor do Departamento $\mathrm{Na}$ cional de Saúde e responsável por sua implementação. A reforma se constituiu como a principal referência para a política de saúde pública neste contexto, criando uma nova estrutura para os serviços de saúde, que culminou em 1941 com a criação dos serviços nacionais e perdurou até o período posterior à criação do Ministério da Saúde em uma pasta isolada da Educação.

As especificidades da carreira de médico sanitarista foram sendo definidas, não por acaso, paralelamente a estas reformas que procu- 
raram expandir a atuação do Estado na área da saúde pública por todo o país. A nova estrutura institucional que se almejava implantar demandava profissionais especializados, aptos para ocupá-la e gerenciá-la, o que por sua vez exigia que se consolidasse a formação médica nesta área através de cursos especializados como os do Instituto Oswaldo Cruz e do Departamento Nacional de Saúde (DNS). Podemos perceber então que à medida que foram sendo definidas as prioridades para a saúde pública, foram também reafirmando-se os requisitos necessários para a conformação desta especialidade médica de forma regulamentar.

Neste sentido, essa geração possui atributos peculiares pois contribuiu para a construção deste aparato institucional, definindo prioridades e acumulando experiências no trabalho cotidiano pelo interior do país. Atuou tanto como formuladora de propostas políticas para o setor, como agente na condução da implementação dessas políticas. Portanto, o processo de institucionalização da saúde pública que se desenvolve a partir dos anos 30 está intimamente entrelaçado à trajetória pessoal e profissional desse grupo de atores.

Os pequenos trechos selecionados das entrevistas e apresentados aqui representam fragmentos desse cotidiano da saúde pública, que poderá assim ser visualizado, tanto através das experiências de trabalho em diferentes instituições, como também nas descrições referentes às formas de controle e combate a determinadas doenças, acompanhados de inúmeros relatos de viagens. Essas lembranças traduzem, em parte, o formato de organização institucional existente e as concepções que orientavam a atuação profissional possível naquele contexto.

Destaca-se como um fator constitutivo tanto da atuação dessa geração de sanitaristas, como do formato institucional da área da saúde nesse período, a presença do Estado, no caso aqui representado por seus funcionários, nas regiões mais remotas do país. De certa forma, poderíamos interpretar essa presença como uma herança da tradição sanitarista da Primeira República, quando médicos sanitaristas como Belisário Penna, Carlos Chagas e Oswaldo Cruz, entre outros, realizaram expedições pelo interior do país, voltados para os problemas das endemias rurais, destacando a importância do saneamento rural para a construção de uma nova nação. ${ }^{3}$
No período aqui enfocado, os relatos nos permitem acompanhar a presença do poder público em diferentes regiões, através da descrição da atuação dos médicos, de diversos órgãos do ministério, em viagens pelo Brasil. São essas experiências a melhor forma de representação e interpretação desse cotidiano da saúde pública que gostaria de descrever. Através dos relatos de viagens obtemos informações sobre as condições de vida da população local, as formas de controle sobre uma determinada doença e as interpretações e concepções que orientavam a prática médica.

Os relatos definem particularidades da inserção profissional de uma dada especialidade médica e espelham uma forma de conduta, de prática profissional, que caracterizava a atuação da saúde pública. Por um lado, demonstram quais as implicações inerentes ao trabalho profissional do sanitarista naquele momento, que tarefas lhe cabiam. Por outro, traduzem uma forma de gestão política e apontam para alguns dos princípios que orientavam a atuação das instituições públicas de saúde. Cabe ressaltar a ênfase atribuída à necessidade de dedicação exclusiva e carreira de tempo integral, como atributos essenciais ao bom desempenho das atividades do sanitarista, incluindo aí a disponibilidade para as viagens de trabalho.

Essa disponibilidade para viagens se caracteriza assim como uma das marcas constitutivas dessa geração e as lembranças a elas relacionadas despontam como um peculiar fio condutor nesse processo de rememoração. $\mathrm{O}$ perfil do sanitarista vai sendo desenhado como um viajante que conhece todos os recantos da região sob sua responsabilidade, que conhece as condições reais de vida e saúde da população que necessita ser assistida. Estes são aspectos constitutivos da identidade do grupo, que ressurge neste processo de rememoração, como havia indicado Bobbio na citação inicial.

Os trechos selecionados das entrevistas falam acima de tudo dessa presença do poder público no interior do país, através da experiência de trabalho em diferentes instituições como a Fundação Rockefeller, o Serviço Nacional da Peste do Departamento Nacional de Saúde, a Campanha do Tracoma do Departamento Nacional de Endemias Rurais (DNERu), a Fundação Serviço Especial de Saúde Pública (SESP) e as Delegacias Federais de Saúde. Permitem, ao mesmo tempo, que aflorem ri- 
cos detalhes do cotidiano profissional e das condições de vida da população, em um período ainda muito pouco explorado da história da saúde pública brasileira.

\section{O combate à febre amarela realizado pela Fundação Rockefeller}

Em 1923 um acordo entre o governo brasileiro e a Junta Sanitária Internacional (International Health Board) criava o Serviço de Profilaxia da Febre Amarela, delegando à Fundação Rockefeller a responsabilidade pelo combate à febre amarela no Brasil, o que lhe permitiu desenvolver ações de pesquisa e profilaxia da doença em diferentes regiões do território nacional. Este acordo perdurou até 1940, quando então a instituição passou a se dedicar principalmente à pesquisa, auxiliando parcialmente as campanhas de vacinação contra a febre amarela. ${ }^{4}$

O trabalho desenvolvido pela Fundação Rockefeller no combate à febre amarela, durante a década de 1930, será aqui recuperado através dos relatos do dr. Fausto Magalhães da Silveira. Dr. Fausto Magalhães nasceu em Maceió (AL), no dia 1o de setembro de 1911; cursou a Faculdade de Medicina da Bahia, diplomando-se em 1933. Em 1936 entrou para o Serviço de Febre Amarela da Fundação Rockefeller, onde permaneceu até o ano de 1940, tendo desempenhado as seguintes funções: assistente do setor Paraná, chefe do setor Santa Catarina, assistente dos setores Mato Grosso e posteriormente Ceará, assistente da chefia da região Sul, membro da equipe designada para assumir o controle e organização do pessoal do extinto Serviço Estadual de Febre Amarela da Secretaria de Saúde do Estado de São Paulo (1939), chefe do setor Bauru (1939) e Rio Grande do Sul (1940). Em 1941 foi nomeado médico sanitarista interino do Ministério da Educação e Saúde (MES), lotado na Divisão de Organização Sanitária (DOS). Nessa época fez diversos cursos entre eles o Curso de Saúde Pública do DNS, concluído em 1943. Em 1944, foi aprovado no concurso do DASP do MES, tendo sido nomeado médico sanitarista do quadro permanente do ministério.

As principais referências aqui destacadas dizem respeito ao período compreendido entre 1936-1940, quando dr. Fausto Magalhães integrava os quadros da Fundação Rockefeller no Brasil. Três atividades básicas que evi- denciam as principais diretrizes do serviço e sua presença no interior do país foram aqui ressaltadas: a visita domiciliar, a confecção de cartografias e a viscerotomia. Todas essas atividades eram realizadas sob a supervisão do médico sanitarista e com a imprescindível atuação dos guardas sanitários.

O serviço de cartografia - encarregado de mapear a região a ser trabalhada - permitia um detalhado conhecimento dos locais que seriam inspecionados, além de um acompanhamento rigoroso da ação dos guardas e do trabalho em execução (indicava a difusão de uma epidemia, os sítios sob intervenção e áreas livres do mosquito). A visita domiciliar indicada como a base do serviço de febre amarela evidencia uma opção de ação política para o combate ao mosquito aedes aegypti, que levava o poder público para o interior das moradias, ou seja, para o espaço privado. Acompanhavam esses serviços as atividades relativas ao trabalho de viscerotomia, essencial naquela época para o controle da febre amarela silvestre, que delegava ao médico o direito de examinar o indivíduo que falecera em condições suspeitas de ter contraído a doença. ${ }^{5}$

Ao serviço de saúde era permitido portanto, a partir do mapeamento da região, inspecionar as casas e até controlar o sepultamento dos mortos, aspectos que atribuíam ao médico sanitarista, ao que tudo indica, função de poder e prestígio. Por outro lado, o médico é mais um elemento de uma estrutura que funcionava de forma hierarquizada e rigorosa, lhe exigindo disponibilidade para viajar às diferentes regiões do país, quando solicitado pelo serviço, além da apresentação de relatórios constantes das atividades que realizava, através dos diários semanais. Estes relatos demonstram como o serviço de combate a febre amarela integrava um conjunto de ações orientadas para o acompanhamento minucioso do cotidiano da população e de seus funcionários.

\section{Estrutura funcional do serviço}

A estrutura (da Rockefeller para o combate da febre amarela) funcionava do seguinte modo: existia aqui no Rio de Janeiro o que se chamava de escritório central. Além dessa chefia, existiam setores regionais e depois tinha as chefias dos estados. Cada estado tinha um diretor estadual, um chefe estadual. Em linhas gerais, era essa estrutura.(...) 
Todos os médicos do serviço eram obrigados a fazer diário. E esse diário era exigido, era obrigatório e todo mundo tinha que fazer. Nesse diário ele contava a sua vida no serviço, durante uma semana. Sábado ele encerrava o diário, datilografava aquele negócio. Mandava para o escritório dele, onde ele estava submetido à chefia imediata. E essa chefia imediata, depois de ler e anotar coisa e tal, mandava pra direção geral (dr. Fausto Magalhães da Silveira, 1995, fita 5$).^{6}$

...se eu for me reportar às minhas primeiras viagens e isso na década de não sei, de 30 e tal etc., eram coisas hilariantes. Inteiramente gozadas; do sujeito chegar como eu cheguei em muitos e muitos municípios e fui o primeiro médico a chegar naquele município. E servia de curiosidade, não é? Todo mundo queria saber, primeiro como era o médico. Tem um médico aqui e tal, vamos ver como é esse médico? E, se decepcionavam em parte, né, porque eu era bem moço (ri) e isso e tal (Fausto Magalhães da Silveira, fita 15. Grifo do autor).

O curioso, é que quando eu entrei na carreira de médico sanitarista, o quadro era de 120 médicos, pra todo o Brasil. O ministério só tinha 120 médicos sanitaristas. De maneira que representava, digamos, uma posição, não digo de prestígio, mas de indivíduos que se esforçaram e que chegaram àquela situação (...) Alguns, principalmente aqueles da minha época, nos mantivemos exclusivamente dedicados à saúde pública e não exercemos nenhuma atividade médica (Fausto Magalhães da Silveira, fita 11).

\section{Visita domiciliar e a importância do guarda sanitário}

O que eu sei é que existia um rigor muito grande no trabalho do guarda, inclusive o guarda visitava, em média, 500, 700 casas por semana. No centro da cidade que tinha muito sobrado podia abaixar até pra 300 e tantos. Mas tudo isso era feito com tal rigor, que inclusive em algumas áreas, nós cronometrávamos o tempo de permanência do guarda em cada visita. Porque uma das coisas mais importantes e que hoje eles não ligam nada, é o serviço de limpeza urbana. O serviço de limpeza urbana representa a base para possibilitar um programa de controle de erradicação do Aedes.

O que eu sei é que, aqueles guardas, cada grupo, digamos, de 6 ou 7 guardas, tinha um guarda-chefe e existia o guarda-chefe geral. De maneira que não existia nenhuma possibilidade do guarda registrar atividades que não tivessem sido realizadas. Porque além do controle do itinerário, nós usávamos um modelozinho que o guarda era obrigado a assinar e datar, da sua passagem. E eles sabiam perfeitamente, se por ventura ele quisesse emprenhar a visita dele, registrando duas idas, já pra semana subseqüente, e não visitando, facilmente seria identificado pelo inspetor, pelo médico e tal. E num caso como esse era dispensa imediata, não tinha nem conversa pra explicar coisa alguma. Era inexplicável (Fausto Magalhães da Silveira, 1995, fita 7. Grifo meu).

E aos poucos nós fomos invadindo a zona rural; e as visitas na zona rural eram feitas na base do jumento, do burro. Tanto que eu, sempre achei, que o Serviço de Febre Amarela comete uma grande injustiça não prestando uma homenagem, como uma estátua ao burro no meio do Brasil. Porque se não fosse o burro, o jumento, nós não poderíamos jamais ter erradicado o Aedes. Na cidade o serviço era feito digamos, no “P2". "P2” era no pé do guarda: pá, pá, pá! Corre de um lado pro outro (Fausto Magalhães da Silveira, 1995, fita 8. Grifo do autor).

Quando o indivíduo entrava na zona rural, já tinha a dupla função de fazer o registro e o mapeamento, pra não perder tempo. Era muito prático. Porque se tivesse uma turma só pra fazer mapeamento, perdia um ciclo de visita. E muitas vezes um ou dois ciclos de visita tornava negativa toda aquela área porque o serviço era feito com muita eficiência, né. O guarda visitava, vasculhava tudo e ia logo eliminando os focos por ventura existentes. E essa turma que fazia esse levantamento na zona rural, tinha a dupla função de guarda larvário e o guarda capturador. Quer dizer, o sujeito fazia logo uma inspeção completa. Porque às vezes, ou quase sempre, é mais fácil você identificar a presença de um foco larvário com a presença de um Aedes alado. Porque aonde existe um alado, existe o foco. De maneira que isso, nós tínhamos essa segurança. Se um guarda dizia que tinha encontrado um alado e que não tinha encontrado um foco, alguma coisa tinha fracassado, não é? (Fausto Magalhães da Silveira, 1995, fita 8).

A febre amarela, toda ela, não digo que repousasse exclusivamente na visita domiciliar. Mas a visita domiciliar era o ponto básico, fundamental, que possibilitou a erradicação do Aedes aegypti. Sem essa autoridade de visitar, não só no serviço de captura, como no serviço de polícia de foco, a periferia das casas, mas dentro 
das casas, teria sido totalmente impossível. É o que a gente observa hoje. Hoje os guardas sanitários não têm nenhuma autoridade para penetrar na casa de ninguém (Fausto Magalhães da Silveira, 1995, fita 9).

\section{O serviço de cartografia: mapeando a região a ser trabalhada}

O Serviço de Febre Amarela treinava quem fizesse cartografia, né? A seção de cartografia era a base da organização do serviço; porque não é possível, você manter um serviço de foco em qualquer cidade, que você não tenha planta atualizada daquela cidade. Por que planta atualizada? Pra você saber o roteiro dos guardas, aonde eles podiam ser encontrados (...) E isso tudo nós fizemos, não só em Santa Catarina, como no Paraná. Esse é um serviço muito importante, porque só podia haver disciplina e organização, com essa seção de cartografia funcionando com toda a eficiência.

E nós tínhamos em cada sede do Estado, uma seção de cartografia que era muito bem equipada. Um cartógrafo na base das informações do guarda, que era muito bom. Porque existiam guardas no serviço que eram verdadeiros artistas! E eu ficava admirado com aquilo e dizia comigo mesmo: "Eu sou incapaz de fazer um serviço desse!" O sujeito chegava numa cidade assim de porte médio, pra começar do nascente, fazia a coisa com uma precisão tal que de posse daquele mapa, você saía e verificava que era rigorosamente o que estava retratado no mapa feito pelo guarda. Tinham uns sujeitos altamente capacitados. É bem verdade, todos eles eram guardas especializados, eram guardas-chefes e que se deslocavam todas as vezes que o Serviço queria organizar esse serviço de polícia de foco em determinadas áreas rurais (Fausto Magalhães da Silveira, 1995, fita 8).

...um sujeito chegar num serviço desse, olha pro mapa, você sabe a localização de todos os guardas, né? Você sai dali se não encontrar aquele guarda, ele tá perdido. Aí você... O carro era coisa rara. Noventa por cento dos guardas ouviam aquele raro ruído de automóvel e diziam: É o doutor que vem aí! Você sabe que um guarda uma vez, viu o carro, tinha um muro... Ele estava fora do itinerário dele. Pulou o muro e quebrou a perna, o pé? Coisa terrível! (Fausto Magalhães Silveira, 1995, fita 6).

\section{Viscerotomia para o diagnóstico da febre amarela silvestre}

A viscerotomia era a base do Serviço da Febre Amarela Silvestre. Nós só podíamos detectar a presença do vírus da febre amarela amazônica silvestre através da positividade nos exames de viscerotomia.

As atividades de Mato Grosso eram essas de sempre, de todos os lugares, era resolver problema de recusa de visita, recusa de viscerotomia. Porque a viscerotomia era um problema. Você nem queira saber! Uma série de complicações que dava esse Serviço de Viscerotomia (...)

Eu recebi uma notificação pra ir à Santa Rita do Araguaia. Um lugar terrível! Nos cafundós dos Judas... E me disseram: 'É uma missão arriscada, porque você tem que fazer uma viscerotomia num cadáver já sepultado. Apenas para demonstrar a autoridade do serviço. $O$ viscerotomista, tá aqui o telegrama, notificou que foi impedido de fazer a viscerotomia.'(...) impedido pela família. Era um sujeito de certo prestígio e aí o delegado que aliás não devia ter dado ordem pro sepultamento, porque só com visto do nosso representante é que os cadáveres eram sepultados, e esse foi sepultado sem o visto (...)

Todos os atestados de óbito passavam pelo crivo do nosso representante. E o nosso representante tinha instruções. As instruções eram as seguintes: todo indivíduo que morresse com menos de 10 dias de doença, tinha que ser viscerotomizado. Os outros não, dava o visto e liquidou o assunto. Nesse caso, o atestado não foi encaminhado ao nosso representante e dado o poderio do dono do defunto, digamos assim, foi sepultado. E a minha missão era ir lá, fazer a exumação, fazer a viscerotomia e dar uma chamada no responsável e regressar à minha base no serviço. Aí nesse caso teria que tomar essas providências (...)

E hoje, posso lhe garantir, que se houvesse um serviço de viscerotomia como nós tínhamos nessa época, teríamos problemas imensos. Você imagina 50 anos atrás, onde o cadáver era uma coisa inviolável! Um negócio sério (Fausto Magalhães da Silveira, 1995, fita 7).

Quando atuávamos nos municípios, sempre procurávamos elementos do município pra nos dar apoio na realização de certas tarefas, como por exemplo o serviço de viscerotomia. A febre amarela não podia realizar com pessoal próprio o serviço de viscerotomia em centenas e centenas, não só de municípios como em distritos. Principalmente em distrito e aí nós aproveitá- 
vamos elemento local, dos locais, para realizar esse serviço e pagávamos por produção. Bem ou mal, abria uma janela pra possibilidade de fixarmos uma unidade por mais modesta que seja. Não só no município como num distrito desses municípios pobres (Fausto Magalhães da Silveira, 1995, fita 19).

Eu fui fazer levantamento de certas áreas. Eu me lembro que eu estive também muito lá em... no final dessa estrada Noroeste do Brasil. Ela termina... Qual é essa cidade? Só vendo no mapa. Me recordo que eu fui nessa cidade. Levei alguns dias lá. Que a pensão, a divisão dos quartos era com lençol. O lençol é que dividia. E que eu, parece que eu fui lá, entre outras coisas, treinar um viscerotomista. Porque quando nós instalávamos o Serviço de Viscerotomia, nem sempre a pessoa encarregada tinha uma qualificação pra fazer uma viscerotomia. Tinha que dar um pequeno talho debaixo do epigástrio direito. O viscerótomo tinha que ser inicialmente fechado, depois dois ou três centímetros abria o viscerótomo, introduzia e aquilo tinha uma calha e essa calha cortava um pedaço do fígado que entrava dentro do viscerótomo. E, de vez em quando, os viscerotomistas encontravam dificuldade e o médico tinha que ir lá e esperava que morresse uma pessoa para que ele fizesse uma viscerotomia (Fausto Magalhães da Silveira, 1995, fita 7. Grifo meu).

As atividades normais do serviço eram essas: a viscerotomia, era o serviço de polícia de foco e uma investigação ou outra epidemiológica pra constatar a presença ou não da febre amarela, principalmente rural (Fausto Magalhães da Silveira, 1995, fita 8).

\section{O Serviço Nacional da Peste do Departamento Nacional de Saúde e sua atuação no Nordeste brasileiro}

O Serviço Nacional de Combate à Peste Bubônica foi criado em 1941, complementando a reforma de Gustavo Capanema em curso desde 1937, orientada pela preocupação de implementar uma estrutura centralizada de serviços de saúde pública em todo o território nacional. O controle da peste bubônica antes da criação dos serviços nacionais ocorria no âmbito das atividades das Delegacias Federais de Saúde e suas circunscrições, que possuíam sedes nas principais capitais de cada região. ${ }^{7}$

Os trechos selecionados dizem respeito ao período que antecedeu a criação do serviço, com referências ao trabalho desenvolvido pelas Delegacias Federais de Saúde, em conjunto com os Departamentos de Saúde dos estados e principalmente, ao período posterior a 1941, descrevendo as atividades realizadas pelo Serviço Nacional da Peste. Falam da experiência de dois médicos sanitaristas que trabalharam durante vários anos no Nordeste, nestes serviços: o dr. Almir de Castro e o dr. Celso Arcoverde de Freitas.

Almir Godofredo de Almeida e Castro nasceu em Salvador (BA), em 4 de dezembro de 1910 e faleceu no Rio de Janeiro. Diplomouse pela Faculdade de Medicina do Brasil em 1931. Em 1938 foi designado delegado federal de saúde da IV região (que englobava os estados do Rio Grande do Norte, Paraíba, Pernambuco e Alagoas) ficando até 1940. Nesse ano ingressou como assistente no Serviço de Estudo das Grandes Endemias (SEGE), do Instituto Oswaldo Cruz, indo em seguida para os EUA, onde obteve, em 1941, o diploma de Master of Public Health, pela Universidade John's Hopkins. De volta ao Brasil em 1942, foi chefe da Seção de Administração Sanitária da Divisão de Organização Sanitária (DOS) para, em seguida, ser convidado a dirigir o recém-criado Serviço Nacional de Peste do Ministério da Educação e Saúde. Ali permaneceu até 1953 quando então foi criado o Ministério da Saúde.

Celso Arcoverde de Freitas nasceu a 3 de outubro de 1913, em Pernambuco, diplomando-se em 1934 pela Faculdade de Medicina de Recife. A partir de 1938 foi médico auxiliar, no distrito de Caruaru (PE), da Delegacia Federal de Saúde desta região, quando começou seu trabalho com peste. Em 1941 assumiu a chefia do 4o setor do Serviço Nacional de Peste do Estado de Alagoas, subordinado ao Ministério da Educação e Saúde (MES). Fez o curso de especialização em peste do Departamento Nacional de Saúde (DNS), diplomando-se em 1943 e o curso básico de saúde pública do Instituto Oswaldo Cruz (IOC-DNS) em 1946. Foi contratado, em 1947, como médico especializado do Serviço Nacional de Peste (SNP), sendo que a partir de 1950 assumiu a chefia da 1a circunscrição de peste - área do Nordeste (Ceará, Paraíba, Pernambuco e Alagoas). Com a criação do Departamento Nacional de Endemias Rurais (DNERu), em 1956, foi designado para coordenar a Campanha contra o Tracoma. Em 1958 foi sub-chefe do gabinete do Ministério da Saúde. A partir de 1959 foi 
assistente de Mário Magalhães da Silveira e, posteriormente, professor da disciplina fundamentos socioeconômicos da Escola Nacional de Saúde Pública (ENSP).

As informações relativas ao Serviço Nacional da Peste aqui selecionadas falam da atuação destes dois médicos sanitaristas, ressaltando seu papel como administradores de saúde, característica claramente definida por dr. Almir quando afirma que $O$ sanitarista é sempre um administrador, deve sempre ser um administrador. Quem não gosta de administrar, não deve ser sanitarista (Almir de Castro, 1994, fita 4). Esta postura transparece por exemplo, na preocupação com a formação de recursos humanos especializados para o combate à peste, através da realização de cursos preparatórios que auxiliavam por sua vez na seleção de pessoal.

A importância atribuída ao trabalho do guarda sanitário para o desenvolvimento das atividades de combate a peste é outro aspecto acentuado pelos depoimentos, à semelhança das referências ao trabalho desenvolvido pelos guardas da Fundação Rockefeller. Este é um aspecto que sugere a hipótese de que a função do guarda sanitário despontava como essencial para o desenvolvimento das atividades de saúde pública naquele período.

As viagens por diferentes cidades do Nordeste, região na qual atuavam neste período, reafirmam-se como atividades fundamentais ao trabalho de saúde pública, refletindo a intenção de um acompanhamento minucioso da execução dos serviços. A forma de gestão então constituída para a execução deste serviço demandava o deslocamento do médico pela região sob sua responsabilidade, permitindo que conhecesse efetivamente as condições de saúde existentes e garantindo a presença do poder público nos recantos mais remotos do país.

Ressaltam-se também alguns trechos que transmitem claramente o idealismo que conduzia a atuação destes profissionais, observada através da dedicação integral ao trabalho no qual se engajaram e das condições, muitas vezes precárias, enfrentadas para estabelecer medidas de controle e combate a peste bubônica.

\section{A experiência na Delegacia Federal de Saúde e os primeiros contatos com o problema da peste}

A criação das Delegacias Federais de Saúde traduzem uma opção de gestão administrativa condizente com os princípios que orienta- ram as reformas nesta conjuntura. Elas se constituíam como órgãos de representação federal com atuação nas circunscrições regionais onde eram instaladas e atuavam como intermediárias entre os governos e departamentos estaduais e os serviços federais, instrumentos, portanto, do processo de centralização desencadeado no governo Vargas. Dessa forma a política de saúde passa a ser executada seguindo as especificidades regionais, mas sob supervisão federal. ${ }^{8}$

Nesse tempo (1937), as Delegacias de Saúde eram responsáveis por serviços que depois se tornaram serviços independentes. Por exemplo, o Serviço Nacional de Peste, naquela ocasião, não existia ainda. Então quem fazia o trabalho de peste na região eram as delegacias; por acaso a minha era região de peste, motivo pelo qual depois eu fui nomeado diretor do Serviço $\mathrm{Na}$ cional de Peste, onde fiquei doze anos. Aí eram atividades que os estados não estavam muito preparados pra fazê-las, e nós estávamos preparados, porque inclusive tínhamos verbas para isso tudo. Então as Delegacias de Saúde foram muito bem-recebidas sempre. Porque (...) era fazer um trabalho que normalmente caberia ao Estado se não houvesse um órgão federal. Não é? (Almir de Castro, 1994, fita 3).

Ernani Braga, Valério Konder e Mário Magalhães eram amigos intimos meus e eu montei este grupo para me assessorar na Delegacia Federal de Saúde da IV Região. Eles eram sanitaristas, tinham que ser designados pra algum lugar. Mas aceitaram ir trabalhar nesses lugares porque eram pessoas muito especiais. Porque eram todos "out of records", eram pessoas de esquerda e tinham interesse em trabalhar junto do povo, não é? E agora tínhamos os nativos também. Nós tínhamos lá o Oscar de Brito, tínhamos o Lessa, tínhamos várias outras pessoas, engenheiros sanitários (Almir de Castro, 1994, fita 3. Grifo meu).

E depois, no exercício do Serviço Nacional de Peste eu percorria essas zonas todas duas vezes por ano. Inteirinha. Eu ia lugar por lugar. Nós tínhamos a circunscrição, que era uma só e depois então tinha o setor e depois o Posto de Saúde. Eram três hierarquias. (...)

A peste era uma coisa que vinha desde, vamos dizer, cercanias do Piauí, compreendeu? Mas era principalmente Ceará - Rio Grande do Norte, mais ou menos escapava um pouco de peste -, era Pernambuco, Paraíba, Alagoas e um pouco Bahia. Na Bahia nós tínhamos uma circunscrição. Outra no Ceará, outra em Recife. E 
então a circunscrição se dividia em setores e os setores se dividiam em distritos. Então cada setor e cada distrito tinha um médico. Pra isso nós fizemos cursos que inclusive tinha especialistas estrangeiros que nós convidávamos, especialistas em entomologia aplicada, por exemplo, de zoólogos que trabalhavam com ratos. E então nós fizemos esses cursos, três cursos diferentes para recrutar o pessoal do Serviço Nacional de Peste (...) pra serem escolhidas para os diferentes postos, porque era uma coisa que ia começar, não é? Eram escolhidas em cada região, pra ficar na região e de acordo com o aproveitamento nesses cursos. E a essas pessoas era dito que era tempo integral e que não podiam clinicar, nem ter laboratório nem coisa nenhuma. Somente se estivesse numa zona que não tivesse um médico, aí atenderia por uma questão de humanidade (Almir de Castro, 1994, fita 2. Grifo meu).

Agora, a prevalência da doença foi tão grande, o surto foi tão grande, em Pernambuco naquela época de 1938-39-40, que não houve chance pra eu fazer clinica. Porque imediatamente eu era chamado pra atender doentes nos mais distantes lugares. Caruaru era o epicentro de uma área pestosa enorme. Então eu saía de Caruaru, ia atender ao Norte, vamos dizer ao Norte, o povoado de Torres, que hoje é o município de Toritama; Frei Miguelinho era outro local, que deu peste, depois Vertentes. Quando eu estava em Vertentes, já estava subindo para Surubim, Umbuzeiro e Paraíba. Quer dizer, eu andava 40, 50 quilômetros ao norte de Caruaru e outro tanto ao sul. E quando menos a gente esperava, vinha uma notícia: "Vá atender casos em Garanhuns..." Porque o médico que atendia peste em Garanhuns, era o chefe do Posto, Vicente Ferrer. Ou ele atendia o Posto, ou ele atendia peste. Aí, então, me jogavam pra lá. Neste Posto não tinha hospital, eu fazia os exames no laboratório do Centro de Saúde de Garanhuns (...)

E eu não consegui me dedicar a clínica por isso, porque era tanto o serviço na zona de peste, de casos humanos e eu viajava tanto naquela área enorme, que aí eu passei a atender dois distritos. Passei a atender o distrito de Caruaru e o distrito de Garanhuns. E a minha experiência com peste foi feita assim, no atrito das circunstâncias que surgiam eventualmente.

Com relação à vontade de viajar, de ir para o interior... acontece o seguinte, eu acho que tinha qualquer coisa no sangue, porque senão, eu abandonaria, se eu não tivesse tendência para suportar esse tipo de vida... eu abando- naria rápido (Celso Arcoverde de Freitas, 1994, fita 4. Grifo meu).

\section{Seleção e treinamento dos guardas para o combate à peste}

A primeira coisa. A seleção. Nós selecionávamos os guardas pela idade ouviu. Nunca antes de 20 anos, 22, gente nova mas nunca novo demais. E também idade acima de 35 anos, não podia. Por que? Porque o trabalho é muito duro na zona rural. É andar a cavalo, andar a pé, passar a semana inteirinha fora pra chegar no fim da semana pra ir pra casa. Você vê, o indivíduo vai, passa um, dois, três, quatro, cinco anos e se casa, aí já vem a complicação. Tem a família, tem o filho, já não quer mais ser transferido de um distrito pro outro não é? Isso já é problema que o administrador sanitário é que vai ter que resolver. É a questão da estrutura dos grupos de guardas sanitários treinados. Agora, o treinamento era o seguinte: todo guarda tem que saber ler, escrever e fazer as quatro operações. Isso não tenha dúvida. Porque tem que escrever, tem que fazer a parte estatística e tal. Agora, eles eram treinados por nós mesmos, no campo. (...)

Então, antigamente, não tinha a peste, não havia as bombas de cianogás, não havia lançachamas, não havia nada disso, não é? Os guardas de malária não tinham as bombas de aspersão, de inseticidas, então o treinamento era muito rudimentar. Era colocar - na parte de peste, vou falar só sobre a parte de peste-as iscas raticidas, nos lugares estratégicos. Então, nós acompanhávamos os guardas, o guarda e o guarda-chefe já habituado, já treinado e dizíamos como deve ser feito e como deve registrar o lugar na cozinha, nos quartos, na sala, não é? Se tem ou não tocas de rato, tudo isso tem que ser registrado e nas costas desse boletim tem um mapa com os pontos cardeais e a localização dos sítios vizinhos, porque a nossa área de trabalho, são seis quilômetros de raio do ponto. Então ali é a ficha de localidade. Essa ficha de localidade, nós fazíamos aquilo de tal maneira bem feito, que nem o IBGE tinha um levantamento de população... Porque a gente sabia quantas pessoas moravam em cada casa e a distância em relação à sede do município. Se tinha ou não estrada de rodagem, se tinha ou não estrada carrossável ou era puramente caminho. Tudo isso era registrado na ficha de localidade. Essa ficha deve ter lá na SUCAM. Se não tocaram fogo (Celso Arcoverde de Freitas, 1994, fita 4). 
Métodos de controle e combate à peste

Porque nos primórdios, quando nós pegávamos um foco de peste com caso humano e com episotia, a área minima a trabalhar era seis quilômetros de raio. Para haver uma certa garantia, nós fazíamos envenenamento, porque, antigamente se fazia envenenamento. Pra desratizar, se fazia o envenenamento do sítio. Isso significava o seguinte: os guardas levavam uma quantidade de papéis, de cartuchos, contendo um fubá envenenado com $15 \%$ de arsênico e com um atrativo que era queijo. Queijo estragado, queijo ardido, peixe... Tudo que tivesse um cheiro bem ativo, para atrair os ratos. (...) Então, nas trilhas de rato nós colocávamos aqueles venenos em pacotes. Isso da época em que se utilizava essa coisa tão precária, para matar rato. Quando não se fazia coisa pior: matar a pau. Botar água no buraco de rato, pra ele sair e ficar caçando. Quer dizer, um absurdo, uma coisa dessas. Mas não tinha outra coisa, pra fazer isso. Isso foi antes da Guerra! Em 1936, 1938. Então, o recurso era muito precário (Celso Arcoverde de Freitas, 1994, fita 4).

Porque aí o conceito passou a ser epidemiológico. Então, a área epidemiologicamente que interessava é uma área em que há fronteiras que limitam a rataria, os roedores. Por exemplo, no sertão, você não encontra roedor em toda parte. Mas nos pés de serra, você encontra. Que é exatamente a área onde a vida é permanente. Onde há sempre um resquício de umidade na maior seca. Eé onde se concentra a população de roedores (...) Resultado, dali, daqueles focos, ai a peste começa a se espalhar para as zonas subjacentes. Vai e se espalha e então você vê. Se o foco é aqui, digamos em Exu e Crato, ele vai andar em torno de 20, 30, 40 quilômetros, às vezes. E às vezes, não é por contiguidade, é per salto. Às vezes são coisas que são levadas digamos... cestas com caroço de algodão e leva a pulga. $O$ próprio rato. Então, ele pode ser transportado de uma área para outra. Porque a expansão da peste pode ser por contiguidade, como uma mancha de óleo que se espalha e ela pode pular, pode ser per salto. E então, é o caso da estrada de ferro, que leva as coisas pra longe. Pois bem. Ai, na época de Barreto fazendo a peste, executando a Campanha de Peste, passou-se a ter outra orientação e a coisa começou a ser feita com base na epidemiologia (Celso Arcoverde de Freitas, 1994, fita 4).

\section{A Campanha de Combate ao Tracoma}

Estes trechos sobre as ações realizadas para o combate ao tracoma foram retirados principalmente do depoimento de dr. Celso Arcoverde de Freitas, referente ao período em que coordenou a Campanha do Tracoma, de âmbito nacional, pelo Departamento Nacional de Endemias Rurais (DNERu) a partir de 1956.

Os relatos aqui apresentados transmitem contundentes descrições sobre as condições de vida no Nordeste nesse período e deixam explícitas as íntimas relações que estas estabelecem com o problemas de saúde descritos - no caso especificamente o tracoma - bem como com as formas utilizadas para enfrentá-los.

A opção adotada para conduzir a campanha ressalta, por sua vez, um aspecto interessante ao instituir um tratamento dinâmico, diferente do que havia até então através de posto fixo. Instituiu-se um modelo de ação que fazia o representante do poder público ir a população e não unicamente esperar que o doente procurasse pelo serviço. Mais uma vez constata-se a incorporação das viagens de trabalho à rotina das atividades desenvolvidas pelo serviço de saúde, marcando presença no interior do país.

\section{Descrição da doença e meios de controle}

Mas também tinha esse grupo dentro do ministério, que mal ou bem se dedicava exclusivamente... É como eu lhe disse, os serviços eram bons. Bons. Eu encontrei esse pessoal trabalhando lá no sertão do Nordeste, entendeu? Em condições as mais precárias. Você montava no lombo do burro, botava um saco de paçoca e ia em cima da serra pra ver o quê que estava acontecendo. E às vezes não tava acontecendo nada. Mas você, tava lá. Tracoma, aquilo era incrível! A gente chegava lá no sertão, onde as equipes já estavam trabalhando e não tinha onde ficar. Ficava na casa de alguém. Aquelas casas não tinham parede até em cima. Tinham um telhadão, a parede era meia parede, e quando dava de manhã assim, o mais velho dizia de lá: "Não lava o rosto nessa bacia". A gente: "Por quê? Por quê!” Porque o tracoma tava ali. O sujeito usando a mesma bacia, sem higiene. A gente ia aprendendo (Aldo Villas Boas, 1995, fita 2. Grifo do autor).

Os postos eram subordinados, eram dirigidos pela Divisão de Organização Sanitária do 
DNS. Porque eram 37 no Brasil todo, durante alguns anos. Foram crescendo, crescendo. Quando eu peguei a Campanha de Tracoma, havia 37 postos. Mas Posto só fixo, não andava. Aí, foi a grande mudança que nós fizemos. A campanha que era antes toda ela, de tratamento em posto fixo, passou a ser feita em tratamento dinâmico. Quer dizer, o guarda era treinado, levava o material pro campo, preparando uma ficha domiciliar. Por que? Porque a doença é uma doença que não é uma doença familiar. Quando você tem um indivíduo com tracoma, geralmente todas as outras pessoas pegam (Celso Arcoverde de Freitas, 1994, fita 4. Grifo meu).

Mas esses doentes, por exemplo, de tracoma eram todos tratados no Posto. E por que? Porque a grande maioria desses doentes, que procurava o Posto, ia na época aguda do tracoma. Geralmente agravado pelo dor-d'olhos, que é a conjuntivite epidêmica. O tracoma é uma conjuntivite granulosa, aparentemente, benigna, no princípio. A dor-d'olhos é uma conjuntivite epidêmica, devido a um outro germe, é o Coroix, é uma outra bactéria. E ainda tinha outra doença de olho, que dava um olho muito vermelho assim, em volta e que no Ceará o povo chamava olho em fita, é sapiranga. O nome piranga é de vermelho mesmo, é uma denominação indígena. Sapiranga, olho vermelho, deu muito isso lá no Crato, em Juazeiro; aquela zona do Cariri era o quartel general dessas doenças: tracoma, sapiranga e dor-d'olhos. O dor-d'olhos, que é uma doença aguda, é epidêmica. Quando dá, dá em todo mundo; em criança; é na época de inverno, uma época que tem muito mosquitinho, aquele mosquitinho miudinho, que não é mosquito não, é mosca, mesmo. Porque eles não têm ferrão. Eles lambem a secreção e transmitem pro outro.

Eu comecei a me interessar por tracoma e ver o que era tracoma, quando ainda era do Serviço de Peste. Quando eu trabalhava na peste, naquela zona lá do sertão do Cariri, eu visitava os postos de Tracoma de Barbalha, visitava o Posto de Tracoma de Exu, principalmente, que eu tinha um amigo lá, que era o chefe do Posto e eles operavam. Eu vi crianças de 1 ano, 2 anos de idade, a gente tirava assim, no posto aquelas mosquinhas, Ipélatis.

E assisti também operações que eles faziam muito lá; as operações de consertar a pálpebra, o tarso, que é o arcabouço da pálpebra, é uma parte meio cartilaginosa que vira, forma uma cicatriz de tal ordem que os cílios começam a passar em cima da córnea. E com as infecções que ocorrem, termina evoluindo uma úlcera e muita gente cegou totalmente ou parcialmente ou pelo menos comprometeu muito a sua visão porque não teve tratamento. Então, criou essa seqüela que se chama entrópio-triquíase, quer dizer, um encurvamento do tarso que é esse arcabouço aqui pra pálpebra e os cílios começam a irritar. E uma coisa muito natural, que os sertanejos lá faziam, aqueles que tinham isso, era arrancar. Arranca e a coisa piora. Porque quando vai nascendo, nasce mais duro aqueles cílios. E aí, começa a irritar, vem a córnea, vem a úlcera, vem uma cicatriz que fica tapando o raio luminoso, não pode mais passar ali. Fica cego. Quando não fica cego totalmente, fica cego economicamente, como diziam os sanitaristas da OMS. Porque não pode realizar nenhum trabalho que dê ganho pra vida. O sujeito tem que viver como um inválido.

E eu vi muito mendigo, muito sujeito pedindo esmola numa cuia de queijo, porque antigamente se vendia mais esse queijo de bola, esse de cuia, no Crato, em Exu e principalmente em Juazeiro. Porque Juazeiro tinha a fama do padre Cícero. Eu via nas feiras de Juazeiro, o pessoal cantando, pedindo esmola e cantando aquelas toadas lentas assim... igualzinho ao baião de Luiz Gonzaga. Porque Luiz Gonzaga é de lá. E aquilo ficou no ouvido dele, essas cantigas de Luiz Gonzaga têm um longínquo daquelas cantigas de cego pedindo esmola nas feiras. Muito tracomatoso cantou sem saber o baião ou pelo menos aquela frase musical que dá pra fazer o baião. O ritmo do baião, vem daí. Luiz Gonzaga é de lá e aproveitou o ritmo (Celso Arcoverde de Freitas, 1994, fita 4. Grifo meu).

\section{O trabalho na Comissão Brasileira Demarcadora de Limites do Setor Oeste}

Estes pequenos trechos retirados do depoimento do dr. Bichat Rodrigues destacam a grande preocupação com as endemias rurais entre os médicos sanitaristas da época, reafirmando-as como objeto privilegiado de atenção. Falam de seu trabalho em regiões distantes, junto aos índios da Amazônia, de seus vínculos com o dr. Evandro Chagas e sua equipe e se constituem como mais um exemplo do trabalho de dedicação efetuado nas mais diferentes regiões do país por esta geração de médicos sanitaristas.

Bichat de Almeida Rodrigues nasceu em 7 de agosto de 1912, em Teresina (PI). Diplo- 
mou-se em 1936 pela Faculdade de Medicina da Universidade do Brasil. Os trechos aqui selecionados dizem respeito ao início de sua vida profissional. Seu primeiro trabalho depois de formado foi como médico da Comissão Brasileira Demarcadora de Limites do Setor Oeste, de 1937 a 1939. Neste ano foi convidado por Evandro Chagas para trabalhar no Instituto Oswaldo Cruz (IOC), no Serviço de Estudos das Grandes Endemias (SEGE). Em 1940 passou a ser assistente técnico do Instituto de Patologia Experimental do Norte (IPEN), situado em Belém (PA). Foi ainda médico da Delegacia Federal de Saúde da 3a Região, que reunia Pará e Maranhão em 1941-1942. Em 1942 fez o curso de saúde pública no Instituto Oswaldo Cruz do Departamento Nacional de Saúde, para em 1943 realizar concurso para o Ministério da Educação e Saúde como médico sanitarista.

...Em 1937 eu fiz um estágio de três meses com o dr. Evandro Chagas em Manguinhos e depois, então, ele me convidou pra passar no serviço dele em Belém, junto com Leônidas Deane, Neri Guimarães, Gervásio Brito Melo. E ele gostou muito de mim, tanto que eu passei a trabalhar em equipe com ele e fui pra Comissão de Limites onde passei dois anos, sempre mantendo relação com ele e mandando material, coletando coisas do interior pra mandar. Era interessante. De Manaus a Tabatinga (...)

Bom, as pesquisas dele estavam todas vinculadas a esses estudos das grandes endemias, ele estava sempre procurando descobrir e encaminhar a solução de alguma doença que ele fosse descobrindo na área; pra isso foi criado o instituto por ele-que depois recebeu o nome deleo Instituto de Patologia Experimental do Norte passou a se chamar Instituto Evandro Chagas quando ele morreu naquele desastre. Nosso campo de ação era muito no Abaeté, uma cidade perto de Manaus, de Belém, mas que tinha um trabalho a ser desenvolvido. Então se acompanhava tudo que estava ocorrendo em relação a essas doenças, a malária e outras pra ver o que que tava ocorrendo e eles participavam ficando no campo, inclusive acompanhando o desenvolvimento dessas doenças pra saber que providência podia ser tomada para melhorar as condições de saúde, entendeu? (Bichat de Almeida Rodrigues, 1995, fita 1).

Todas aquelas cidades em que eu passei quando subi pra fronteira, na lancha da Comissão de Limites, e aí você não tinha médico senão nas duas pontas... E então os prefeitos das cidades, onde costumava passar a lancha subindo pra fronteira, telegrafavam para o coronel e pediam para ver se o médico podia parar para examinar e dar uma assistência de alguns poucos dias à população local. Eu fiz isso em toda aquela extensão até chegar em Tabatinga; eu estava acampado numa barraca a umas seis horas de Tabatinga só. Aí eu fiquei morando durante três meses em barraca, empoleirado lá em cima do barranco porque o rio Amazonas enchia nesse local em que eu fiquei acima do nível do rio uns seis metros. Eu armei minha rede de uma árvore para a outra aí dentro da barraca e fiquei acampado. E assim nesse local eu via quando chegavam os indios pra serem atendidos por mim. A Comissão de Limites me dava o que chamava uma ambulância; eram vários caixotes com medicação e eu ficava aí atendendo os indios. Eu quando abria minha barraca de manhã, eles já estavam circulando com os barcos embaixo, no igarapé, esperando que eu abrisse. Eu abria, eles chegavam, eu atendia uma média de oitenta a cem índios por dia, menos no fim de semana que eles não vinham... (Bichat de Almeida Rodrigues, 1995, fita 1. Grifo meu).

\section{Fundação SESP: autonomia administrativa e prioridade com o interior}

O Serviço Especial de Saúde Pública (SESP), como é de amplo conhecimento, foi criado em 1942 a partir de um convênio entre o governo brasileiro e o governo americano, este representado pelo Instituto de Assuntos Interamericanos (IAIA), com o objetivo de prestar assistência médica às áreas onde se desenvolviam atividades econômicas estratégicas naquela conjuntura de conflito internacional. Com o fim da guerra, paulatinamente os americanos vão se retirando da gestão do serviço, que passa cada vez mais a contar com a participação de técnicos brasileiros. O SESP perdurou como uma instituição autônoma no interior do Ministério da Saúde até o ano de 1990, quando foi extinto no governo de Fernando Collor de Melo.

Durante esses 48 anos de existência expandiu sua atuação por outros estados do país e desenvolveu atividades principalmente nas áreas de assistência médica e saneamento básico. Foi alvo de grande polêmica em torno de seu modelo institucional, de suas prioridades 
de ação e da autonomia que gozava no interior do ministério, permanecendo totalmente desvinculado dos demais serviços de saúde pública. ${ }^{9}$

Os trechos aqui selecionados sobre o SESP foram recortados do depoimento concedido pelo dr. Aldo Villas Boas. Dr. Aldo Villas Boas nasceu em Fortaleza (CE), no dia 13 de julho de 1920. Cursou a Faculdade de Medicina da Universidade de Recife, diplomando-se em 1943. Sua especialização profissional se deu no campo da tisiologia, tendo trabalhado em vários órgãos nessa área, como na criação e direção da Divisão de Tuberculose da Secretaria de Saúde do Estado de Pernambuco em 1948, e na superintendência da Campanha Nacional contra a Tuberculose (CNCT) a partir de 1950. Ampliando sua atuação na área da saúde pública passou, a partir de 1964, a desenvolver atividades na Fundação Serviço Especial de Saúde Pública (FSESP): foi coordenador de estudos especiais do Setor de Coordenação e Planejamento e, em 1965, diretor da Divisão de Saúde da Comunidade. Nesses anos foi também consultor da Organização Pan-Americana da Saúde/Organização Mundial da Saúde (OPAS/OMS). A partir de 1973 assumiu o cargo de superintendente do SESP, no qual permaneceu até 1985.

O SESP, desde os primórdios de sua fundação, privilegiou o investimento em áreas do interior, deixando explícita sua intenção de atuar em regiões de nítido interesse econômico para o desenvolvimento do país. Dessa forma, o aspecto que tem sido destacado ao longo dos depoimentos aqui apresentados, ou seja, a presença do poder público no interior do país, pode ser visto como fator constitutivo deste serviço; ele existia com o objetivo claro de atuar fora dos grandes centros urbanos. Entretanto seu modelo de ação diferia daquele implementado pelo Departamento Nacional de Saúde, apesar de ser possível identificar semelhanças em alguns aspectos.

Em primeiro lugar, o SESP conciliou atividades na área de medicina preventiva com medicina curativa, em contraposição ao DNS que enfatizava ações preventivas. Em segundo lugar, privilegiou investimentos no setor de saneamento básico, dando grande destaque ao controle no abastecimento de água, acompanhado da noção de que “água é saúde”. Ações preventivas na área de saneamento básico podem ser apontadas como uma das principais marcas da atuação do SESP, explicitando uma filosofia de trabalho diferenciada, que repercutia numa política de saúde com características que lhe eram peculiares. Essas diferenças talvez expliquem, em parte, os debates e divergências que existem em torno da instituição.

Os trechos selecionados abaixo permitem uma primeira aproximação desse modelo de ação e contribui para o mapeamento do universo institucional abrangente, que compunha o campo das políticas públicas de saúde.

\section{Filosofia de trabalho}

... os primeiros quinze anos da Fundação Especial de Saúde Pública foram notáveis por vários empreendimentos e várias modificações na filosofia do trabalho. E várias ações pioneiras. São muitas! E imagine-se que foi nesse período que se reuniu a medicina preventiva com a medicina curativa. E isso era, de uma certa maneira, uma novidade, porque havia como que um divórcio entre as duas (Aldo Villas Boas, 1995, fita 1).

Por exemplo, para um cidadão trabalhar em condições difíceis da natureza, em áreas difíceis da Amazônia, ele recebia uma retribuição financeira mais adequada aos riscos que ele corria e ao sacrifício que fazia. Olhe, um desses diretores que são considerados fundadores, que participaram da criação; ele antes de ir para lá, ele se casou e passou trinta dias viajando para chegar ao lugar onde ia servir né? Trinta dias para chegar a Erunepé. Onde é Erunepé? É uma cidade, um município do Estado do Amazonas. Tá lá ainda a unidade do SESP, tinha até hoje. Então se pagava melhor. E isso já é uma coisa que leva ao descontentamento. Por que ganhar mais do que eu? Por vários motivos: porque ele dava tempo integral, porque ele era dedicação exclusiva, porque de noite ou de dia era ele que ia para aquelas, digamos, missões, atender, com os métodos mais simples possíveis, coisas que ocorriam dentro da área. Inclusive os partos e assim por diante (Aldo Villas Boas, 1995, fita 1).

...nós não fomos feitos pra trabalhar nas capitais, nós fomos feitos pra trabalhar no interior e nas áreas de valorização econômica e desenvolvimento de colonização e assim por diante. Áreas de interesse governamental, áreas de interesse para se levar a uma população, aquilo que ela não tinha de jeito nenhum. Então era aí, onde a Fundação trabalhava (Aldo Villas Boas, 1995, fita 3. Grifo do autor).

Então, não é uma cidade grande, mas são várias cidades médias, pequenas, que você vai 
fazer tudo. Vai botar água, vai fazer melhorias sanitárias, vai ver como é que vai controlar o destino dos dejetos da melhor maneira, entendeu? Vai fazer assistência médico-sanitária, toda aquela assistência médico-sanitária que você pode fazer. Então, o que é aquilo? É uma área de valorização econômica, que o país precisa que tenha alguma coisa ali dentro. Então, quantas nós fizemos, quantas? Você vê aí. Veja os vales. Vale do Amazonas, vale do Jaguaribe, vale do Parnaíba, vale do Rio Doce. Todos os vales onde havia um interesse especial, agrícola ou mineral ou o que fosse, estava o SESP com a estrutura de saúde. Dentro do mesmo princípio, da sua doutrina, da sua filosofia de trabalho. Quer dizer, ajudar o progresso do Brasil. Proteger o homem que faz o progresso do Brasil. O homem doente não põe ninguém pra frente. Não há desenvolvimento com homem doente. Só há desenvolvimento com homem sadio. Então, tá lá a Fundação SESP. Não gostavam e por isso as críticas eram muito grandes (Aldo Villas Boas, 1995, fita 8. Grifo do autor).

\section{O serviço de saneamento}

Esses serviços autônomos de águas e esgotos é que se constituíram em autarquias e fundaram uma autarquia municipal, entendeu? Da melhor maneira possível para que ela não ficasse atendendo às injunções do prefeito ou disso ou daquilo. Porque tinha a administração do SESP. A autarquia era administrada pelo SESP. E foram construídos mil e tantos sistemas até 1984, por aí assim, de abastecimento d'água e cerca de 400 autarquias foram instaladas.(...) Você tem um sistema na cidade-sede. Você tinha pequenos sistemas, nas cidades-distritos, nos distritos outros. Dois, três distritos, cinco, seis, conforme. Pequenos sistemas em conformidade com a necessidade da população. Podia ser até uma torneira pública. Podia até ser um chafariz. Podia porque não ia construir um sistema pra 500 pessoas, 200 pessoas e tal. Mas aqueles sistemas eram administrados pelo sistema central. Então, toda população estava servida de água. Era esse o procedimento (...) Quer dizer que foi o primeiro projeto efetivo de municipalização de um serviço de saúde - foi o sistema público de abastecimento d'água. Isso é o pioneirismo do SESP (Aldo Villas Boas, 1995, fita 2).

Os serviços cooperativos melhoraram bastante a possibilidade de atenção, de assistência àquelas populações. Agora, é preciso ver o seguinte: a assistência médica, não era assistên- cia médica pura como o sentido de assistência médica. Já da década de 1950 pra cima, a medicina curativa era também medicina profilática. Quando se negativava uma fonte de contágio, que que se estava fazendo? Profilaxia. Então, não era medicina curativa pelo simples fato de fechar uma ferida e levantar o sujeito da cama. Compreendeu? Você curava o menino. Mas curava o menino não era só porque você curava e não queria que ele morresse, era também para que aquilo não se estendesse dentro de casa, a outros meninos e a outras áreas e assim por diante.

Quer dizer, a medicina curativa não era um imunizante. Mas, essas concepções surgem durante a evolução do trabalho. À medida que você vai trabalhando, vão surgindo as idéias e você vai experimentando (...) Então, é a mesma coisa na organização estrutural. Você apanhava algumas regiões do Estado, Sergipe, por exemplo, que chegou a ter um colosso de unidades de saúde porque a Companhia Vale do São Francisco financiava ao SESP (...) Financiava o SESP pra ele cuidar das unidades e do Estado (...) Então, havia um programa - Programa do Vale do São Francisco. Como tinha o Programa da Amazônia. Naquele tempo eram os programas. Vários programas. Cada programa tinha um chefe, tinha um centro que controlava essa programação. Compreendeu?

Então, você ia procurando fazer alguma coisa que fosse útil. Você, por exemplo, tem um terreno. Você tem uma unidade, tem um terreno, às vezes, bastante grande o terreno; não era pequeno. Então você dizia assim: Vai plantar uma horta rapaz. Mas como eu vou plantar? Eu digo: Vai plantar como o povo. Em cada casa que tiver um terreno vai plantar uma horta, pra comer verdura, comer... qualquer coisa assim. Mas por quê? Ora, porque isso é medicina (Aldo Villas Boas, fita 2).

\section{A presença de João de Barros Barreto}

João de Barros Barreto é aqui destacado pelo papel político que exerceu neste contexto e em função da freqüência com que é citado ao longo dos depoimentos, indício da importância que lhe era atribuída. Atualmente é um personagem pouco conhecido e lembrado entre aqueles que atuam no campo das políticas públicas de saúde, fato que reforçou o propósito de recuperar passagens relativas à sua participação na história da saúde pública brasileira. 
A partir de 1937, quando é empossado por Gustavo Capanema como diretor do Departamento Nacional de Saúde (DNS), Barros Barreto se torna o principal responsável pela supervisão e execução da política de saúde implementada em todo o território nacional. Com um modelo de gestão altamente centralizador, ao que tudo indica, acompanhava detalhadamente o cotidiano dos serviços de saúde em todo o país. Detinha força política para intervir sobre as nomeações para os cargos nas secretarias estaduais, garantindo a orientação política definida pela reforma de Capanema e assegurando sua efetivação em diferentes regiões do país.

Foi também um importante agente na consolidação da carreira de sanitarista, através do investimento em cursos de saúde pública, que favoreciam a formação de especialistas para a área adequados aos serviços criados. Esses cursos aliados a rotina de trabalho que implementara contribuíram para a formação da identidade desse grupo, paralelamente a consolidação dos serviços.

\section{Os cursos de saúde pública}

Nessa época, 1938, foi a época em que João de Barros Barreto estava no auge para a remodelação, a reforma do Departamento de Saúde, não é? Foi quando ele deu duro para fazer o curso básico de saúde pública. E um grupo de jovens começou a trabalhar nisso, inclusive Almir de Castro, Norberto Bica, o Bichat Rodrigues e tantos outros. Mas, nessa época, Barreto insistia junto aos governos estaduais, junto às secretarias de saúde, para atender ao que o Departamento exigia, sob o ponto de vista de bioestatística.

Então, havia uma Divisão de Organização Sanitária que se interessava muito pelos índices sanitários. E aí, nos indices sanitários principais, você vê: clorimetria da água, os coeficientes de mortalidade infantil, o coeficiente de mortalidade geral, o coeficiente de determinadas doenças transmissiveis, como a tuberculose e as agudas, coqueluche, febre tifóide. Tudo isso queriam para levantar a patologia nossa e como estava; em que grau de intensidade essas doenças estavam matando. A princípio, Barreto insistia que mandassem isso. Então, foram criadas as Delegacias de Saúde.

Mas, Barreto, nessa época, insistia em que os diretores de saúde pública dos estados fossem médicos sanitaristas e não médicos clinicos, que têm outra mentalidade, outra visão. E às vezes, políticos. Então, Barreto lutava com os governadores e interventores; a principio com os interventores e depois governadores, para que os secretários de saúde fossem médicos sanitaristas. E oferecia vantagens. Bolsas de estudo; mandava fazer o curso de saúde pública. Muito médico do estado veio fazer o curso de saúde pública, porque Barreto insistia, estimulava. De modo que eu considero Barreto uma das figuras mais importantes na estruturação da nova saúde pública, depois de Carlos Chagas. Houve uma fase típica de Carlos Chagas. Depois veio a fase do Barreto. Eu cito só esses dois nomes, mas no meio também tem o Carlos Seidl, o José Paranhos Fontenelle, aquele de Minas, o Ernani Agrícola, o Bonifácio Costa que era lá do Rio Grande do Sul e tantos outros (Celso Arcoverde de Freitas, 1994, fita 4. Grifo do autor).

Com Barreto foi muito isso; ele botava o pessoal com curso e aqueles melhores aprovados no curso para ir para os vários estados. Então você tinha uma rede de gente que falava a mesma língua, né. E ele orientava tudo e selecionando os melhores para as áreas mais importantes.(...) De modo que a carreira criou esse núcleo inicial, que ficou depois. Depois se conseguiu dedicação exclusiva (Bichat de Almeida Rodrigues, 1995, fita 1. Grifo do autor).

Porque o sanitarista tem que ter uma avaliação social, né. Você tem que conhecer a formação da população; quais são os elementos que você tem que defender mais pra não ter problema de doença. Quer dizer a proteção; a medicina preventiva passou a ser uma norma muito mais importante do que antigamente, não era uma dedicação como você faz hoje na medicina preventiva, que rende muito mais do que uma medicina curativa. De modo que isso que era importante no curso de saúde pública,você preparava o sujeito pra estudar estatística, porque tem que estudar, então a constituição da população, quais são as faixas mais perigosas pra isso e pra aquilo. Tudo isso é importante você fazer num curso de saúde pública e o sujeito ficar especializado e trabalhando nessa área (Bichat de Almeida Rodrigues, 1995, fita 3).

Foi porque nesse período do Barros Barreto, com os contingentes de cursos de saúde pública, quer dizer, os sanitaristas é que levaram a cabo esse trabalho com a prevenção de forma mais sistemática. Quer dizer, nós éramos gerações de pessoas entusiasmadas com saúde pública, quer dizer, nós acreditávamos naquilo. Era gente que não era interessada em clínica. Não é? (...) 
Mas, de um modo geral, esses nossos eram pessoas que toda vida trabalharam em tempo integral (Almir de Castro, 1994, fita 4. Grifo meu).

\section{A presença nos estados}

As Delegacias Federais de Saúde tiveram uma importância muito grande porque elas eram as coordenadoras e orientadoras das ações federais nas diferentes áreas em que elas existiam. E com isso se estava em contato com as autoridades estaduais, com os colegas que serviam não só na delegacia como em outras áreas do estado, de modo que foi de uma importância capital (...) a informação era permanentemente trazida ao diretor geral, dr. Barros Barreto, de modo que com isso havia uma coordenação muito intensa e muito interessante (Bichat de Almeida Rodrigues, 1995, fita 2).

De modo que aí então lá fui eu pra Curiti$b a$, pra ser diretor de saúde dessa maneira. Foi o Barreto quem indicou, porque o Barreto indicava muito os diretores, ele procurava ter um representante do ministério, sempre que possível, chefiando o Departamento de Saúde do Estado e foi o que aconteceu. Eu fui pra lá como diretor geral, nomeado pelo Ribas, mas indicado pelo Barreto (Bichat de Almeida Rodrigues, 1995, fita 1).

E o Barreto, por exemplo, era muito odiado por muitos porque não queria saber das suas dificuldades, ele dizia que você tinha que fazer uma coisa e você tinha que ir pro campo executar aquilo, se virasse pra fazer, depois ele dava valor ao sujeito que tinha feito, mas não podia dizer "não posso"; com ele não tinha não posso, "você vai pra tal lugar agora e estamos conversado", ele mandava. E ele então brigava com muita gente porque ele queria que você viajasse pros lugares, o sujeito vinha com desculpas e ele não aceitava. De modo que ele era um sujeito de um rigor enorme, e como era muito capaz, foi o melhor que teve em toda época da saúde, né. Capaz, trabalhador inveterado, chegava na secretaria, no departamento dele; oito horas da manhã ele já estava lá e saía sete, oito da noite, o motorista ficava alucinado com ele, que não dava nem tempo pra comer direito.(...)

Ele era um homem de uma capacidade que não teve outro igual, capaz, dedicado, ia a tudo que era serviço, chegava, por exemplo, nas valas de malária quando ele visitava o Brasil, um colega que era o chefe disse: "Doutor, daqui por diante o resto é igual". Aí o Barreto disse: "Então vamos ver o igual". E ia até o fim da vala porque o sujeito podia ter mostrado a parte bonita e não ter mais nada, pra adiante já podia estar mal feito. Ele ia a tudo, tudo ele esmiuçava, $e$ era de uma capacidade, ele tinha uma cultura enorme; e um pé de boi no serviço tremendo, de modo que era impressionante (Bichat de Almeida Rodrigues, 1995, fita 1).

O Barreto era um homem muito inteligente e ele via a coisa com um certo realismo. Era um homem que inspecionava os serviços dentro do sistema mais, não digo rudimentar, mas podendo verificar tudo que pudesse existir de bom e de ruim naquele serviço. Exemplificando: ele chegava num centro de saúde qualquer, ele ia no arquivo, abria o arquivo, pegava uma ficha daquelas e ai queria saber os detalhes. Ele pegava uma ficha, pegava outra e tal. E inspecionava aquilo com riqueza de detalhe (...)

Quanto às reformas, todas elas foram feitas dentro de uma estrutura que permitisse o desenvolvimento da saúde dentro dos padrões mais avançados, mais evoluídos. Não que fossem impossíveis de serem realizados. Não. Era realista (...)

A minha impressão é que o Barreto era centralizador. Pelo próprio comportamento dele, a maneira dele agir; mesmo que em épocas diferentes, o governo pretendesse, digamos, descentralizar, mas ele com a autoridade que tinha, com o conhecimento, com a capacidade... Pelo menos as atividades dele eram atividades centralizadoras. Com o prestígio que tinha poderia conseguir mais ou menos verba para esse ou aquele Estado. Logo, indiretamente, o sujeito exerce esse controle. Barreto era uma figura! (Fausto Magalhães da Silveira, 1995, fita 10).

\section{A carreira de tempo integral: símbolo e síntese da especialização em saúde pública}

A pequena história escolhida para fechar a seleção dos depoimentos apresenta um grande valor simbólico em relação ao que se pretendia dar maior destaque neste trabalho. Ela descreve o empenho para assegurar o tempo integral à carreira de sanitarista que sintetiza, na minha interpretação, o idealismo e a dedicação desta geração. Esta ênfase na necessidade de disponibilidade integral à atividade profissional e por conseguinte, na incorporação das viagens à rotina do trabalho, foi um dos principais instrumentos a assegurar a presença do poder público em diferentes regiões do interior do país. 
...o DASP não quis, não sei porque, que mistério era esse, que o DASP não teve sensibilidade e mandou retirar do projeto de 1963 o tempo integral. E aí então nós tivemos uma luta tremenda, lá no Congresso e nós mobilizamos. $\mathrm{Na}$ quela época era mocinho, esse atual, Humberto Lucena. Humberto Lucena era líder lá, e então nós fomos para lá e como era nordestino, conversei com ele, mostramos como era a atividade do Serviço de Peste naquela área, de Bouba, de Tracoma, para que não se retirasse o tempo integral, porque se retirasse, ia haver uma debandada danada dos médicos que faziam saúde pública. Porque saúde pública sem tempo e dedicação exclusiva é mesmo que nada, né? Era um emprego secundário, sem continuidade. Então para que haja saúde pública é preciso que haja especialista, não é? Não precisa ser pago como um marajá, mas que se pague com dignidade e que a pessoa tenha a certeza de que pode pagar a comida do dia de amanhã.

Então o Humberto Lucena ajudou até certo ponto um pouco. Pelo seguinte, ele não teve força pra ir contra o DASP. Agora, houve uma feliz coincidência. Nós estávamos à noite, já era mais ou menos no último dia para a discussão da aprovação daquele projeto de 1963, e ele me disse: Olha, vocês não vão ter vitória, não vai haver isso não, porque o tempo integral não vai passar, não vai ser incorporado, porque o DASP foi contrário.

Mas nós tínhamos a nosso favor uma coisa muito importante. Já fazia parte do Código $\mathrm{Na}$ cional de Saúde o tempo integral. Pois bem, apesar de ter um documento legal, publicado no Diário Oficial, de ter sido regulamentado, eu não me recordo agora o decreto que regulamentou, acho que é 419.000-A. Pois bem, naquela época, nós tínhamos aquele documento oficial publicado no D.O. mas o DASP não ligou. Na última hora o Humberto Lucena chega e nos diz isso. E eu digo: Me apresenta esse cidadão que vai, que está com o parecer do DASP. E ele apresentou.

Era um cidadão que eu esqueci o nome, então, ele disse pura e simplesmente assim: Vocês não vão ter apoio pra isso, porque não têm um documento legal, que mostre que tem tempo integral e dedicação exclusiva.

E eu digo: Tenho, no Diário Oficial.

E ele disse: Então mostre o Diário Oficial.

O meu colega que estava na hora lá, fazendo essas ligações, era Fausto Magalhães da Silveira. Então, o Fausto correu pra ir buscar.

E enquanto isso eu fiquei conversando com esse cidadão do DASP. E eu disse a ele: O senhor pensa que nós estamos discutindo isso pra obter uma vantagem material, melhor salário e que nós somos sanitaristas de asfalto, de ar condicionado? Está enganado. Nós somos sanitaristas que viajamos o Brasil todo. Nós, nesse ponto nós nos parecemos um pouco com os soldados, com o exército, de qualquer lugar.... Aí eu disse: "Você de onde é?".

Ele virou-se e disse: "Eu sou de Pernambuco" Eu lhe digo: "Ótimo! De que município?" Ele disse: "De Bom Conselho"

Ai eu completei: "Bom Conselho de Papacaça." Ele arregalou o olho. Eu digo: "Vou dizer a sua área, se o senhor conhece mesmo aquilo." E aí fui dizendo os nomes dos sítios: Sítio Papacacinha, Fazenda Pires, Fazenda Leão, Fazenda Santa Maria, e saí dizendo todos os lugares de peste, que eu tinha trabalhado antes, lá.

Ele aí, olhou pra mim, pura e simplesmente, pegou o papel que estava datilografado com o parecer, rasgou e fez um à mão, manuscrito. E levou comigo e entregou ao líder, o que estava fazendo a sessão, que era o Humberto Lucena. E assim, eu e o nosso amigo, o meu colega, Fausto Magalhães, testemunhamos a vitória do tempo integral (Celso Arcoverde de Freitas, 1994, fita 16. Grifo meu).

\section{Considerações finais}

O conjunto dos depoimentos aqui apresentados procurou destacar, como fio condutor da exposição, a presença do poder público no interior do país. Essa presença se viabilizava, como foi visto, através da forte hierarquia institucional, calcada em um modelo centralizador e pode ser constatada basicamente no acompanhamento minucioso da execução dos serviços - exemplificado pelo controle do trabalho dos guardas sanitários ou pelos diários de campo exigidos dos médicos - e no idealismo e dedicação dessa geração, que se imbuía da necessidade de viajar e atuar nas regiões mais remotas do país. Meu principal objetivo foi, portanto, ressaltar aspectos que julgo são peculiares a esse grupo e a esse contexto da política de saúde.

Infelizmente os trechos das entrevistas aqui apresentados são pequenos fragmentos de um universo extremamente abrangente, que não se esgota nos limites deste trabalho. Os recortes foram realizados de forma a permitir ao leitor uma visão panorâmica do que era o cotidiano em alguns setores da saúde pública, sem a intenção e sem a possibilidade de uma 
análise minuciosa sobre as inúmeras variáveis que interferiram na execução de políticas públicas de saúde nesse período. São desdobramentos para o futuro.

As lembranças que aqui tiveram a possibilidade de aflorar, através destas trajetórias de vida, mesclam e confundem de maneira contundente vida profissional e privada. Permitem que a experiência desse grupo não se perca e indicam que o esforço de recuperação da memória de parte de nossa história é uma justa homenagem a estes personagens e um resgate necessário do importante papel que em outras sociedades, em outros períodos da história os idosos e suas experiências de vida já desempenharam. Se esperamos que efetivamente as políticas de saúde pública possam alcançar parâmetros mais justos e igualitários não podemos prescindir da experiência e da história dessa geração.

\section{Notas}

1 O projeto Memória da Saúde Pública Brasileira foi desenvolvido no Departamento de Pesquisa da Casa de Oswaldo Cruz/Fiocruz, em conjunto com as pesquisadoras Anna Beatriz Almeida e Wanda Hamilton, tendo constituído um acervo de 110 horas de depoimentos. Contou com a colaboração das bolsistas Christina Helena Barbosa e Maria Beatriz Guimarães, tanto no trabalho de levantamento de dados como no acompanhamento das entrevistas. Da etapa de finalização, participou também a bolsista Jacqueline Lima. Atualmente prossigo com o trabalho de realização de entrevistas e análise do acervo, para o projeto de pesquisa que vem sendo desenvolvido no âmbito de meu doutorado em ciências políticas no IUPERJ/UCAM.

2 Provavelmente aqueles que viveram mais de perto as situações aqui relembradas, ou que conhecem a história da saúde pública brasileira sentirão falta de inúmeros atores que não tiveram suas lembranças aqui contempladas. Isto se deve à impossibilidade de reproduzir neste trabalho todos os depoimentos recolhidos, bem como as experiências profissionais de todo o universo de atores deste período, alguns já falecidos e outros impossibilitados de nos conceder o depoimento que gostaríamos. Procurei selecionar dentre os depoimentos aqueles que ilustravam trajetórias profissionais que perpassaram por diferentes instituições, possibilitando assim ao leitor tomar conhecimento de experiências em diferentes setores.

3 Uma abordagem mais detalhada sobre a saúde pública na Primeira República poderá ser encontrada em Hochman (1998), Lima (1999), Santos (1987), Lima e Hochman (1996) e Lima e Brito (1996).

4 Para maiores informações sobre a história da febre amarela ver Franco (1969) e Benchimol (1999). Sobre a história da Fundação Rockefeller ver Faria (1994) e Cueto (1996).

5 Para informações mais detalhadas sobre o trabalho do serviço de cartografia e viscerotomia realizado pela Fundação Rockefeller, ver Löwy (1998).

6 Todas as palavras destacadas ao longo dos depoimentos citados indicam que o depoente enfatizou-as no decorrer de sua exposição

7 Os 12 serviços nacionais instituídos foram os seguintes: Serviço Nacional da Peste, Serviço Nacional de Tuberculose, Serviço Nacional de Febre Amarela, Serviço Nacional do Câncer, Serviço Nacional de Lepra, Serviço Nacional de Malária, Serviço Nacional de Doenças Mentais, Serviço Nacional de Educação Sanitária, Serviço Nacional de Fiscalização da Medicina, Serviço Nacional de Saúde dos Portos, Serviço Federal de Bioestatística e Serviço Federal de Águas e Esgotos. O Serviço de Febre Amarela e o Serviço de Malária do Nordeste antecederam a criação dos respectivos serviços nacionais, pois já haviam sido criados, vinculados às ações da Fundação Rockefeller. Ver lei no 378 de 13/01/1937.

8 Com a reforma de Capanema foram criadas oito Delegacias Federais de Saúde, divididas nas seguintes regiões: 1) Distrito Federal e Estado do Rio de Janeiro; 2) Território do Acre e Estados do Amazonas e Pará; 3) Estados do Maranhão, Piauí e Ceará; 4) Estados do Rio Grande do Norte, Paraíba, Pernambuco e Alagoas; 5) Estados de Sergipe, Bahia e Espírito Santo; 6) Estados de São Paulo e Mato Grosso; 7) Estados do Paraná, Santa Catarina e Rio Grande do Sul e 8) Estados de Minas Gerais e Goiás. Ver Brasil, lei no 378 de 13/01/1937.

9 Julgo que extrapola os objetivos imediatos deste trabalho uma análise pormenorizada sobre a polêmica que gira em torno da atuação da Fundação SESP, que perdura até os dias de hoje. Apesar dessa divergência sobre a instituição poder ser constatada nos depoimentos, a partir de interpretações bem distintas, ela merece uma investigação minuciosa para que seja possível uma interpretação analítica mais consistente. As informações que aqui são apresentadas representam, portanto, um olhar sobre a instituição que, obviamente, é condicionado pela experiência de trabalho do depoente, bem como pelo cargo que ocupou na instituição durante tantos anos. Isto, entretanto, não invalida a riqueza das informações prestadas. 


\section{Referências bibliográficas}

Benchimol J 1999. Dos micróbios aos mosquitos: febre amarela e a revolução pausteriana no Brasil. Ed. Fiocruz e Ed. UFRJ, Rio de Janeiro.

Bobbio N 1997. O tempo da memória. Campus, Rio de Janeiro.

Castro Santos LA 1985. O pensamento sanitarista na Primeira República: uma ideologia de construção da nacionalidade. Dados, vol. 28, no 2 .

Castro Santos LA 1987. Power, ideology and public health in Brazil (1889-1930). Ph.D. thesis. Harvard University.

Cueto M 1996. Los ciclos de la erradicación: la Fundación Rockefeller y la salud pública latinoamericana, 1918-1940, pp. 179-202. In Cueto M (ed.), Salud, cultura y sociedad en América Latina: nuevas perspectivas históricas. IEP-OPS, Lima.

Faria LR 1994. A fase pioneira da reforma sanitária no Brasil: a atuação da Fundação Rockefeller (1915/ 1930). Dissertação de mestrado. Instituto de Medicina Social, UERJ.

Fonseca CMO 1992 Origens do Ministério da Educação e Saúde Pública: criação e estrutura administrativa durante o governo provisório. Casa de Oswaldo Cruz, Fiocruz, Rio de Janeiro. (Digit.)

\section{Depoimentos}

Castro A 1994, (8h) Rio de Janeiro, COC/ Fiocruz. Freitas CA 1994, (26h) Rio de Janeiro, COC/Fiocruz. Rodrigues BA 1995, (3h) Curitiba, COC/Fiocruz.

Silveira FM 1995, (22h) Rio de Janeiro, COC/Fiocruz. Villas Boas A 1995, (11h) Rio de Janeiro, COC/Fiocruz.
Fonseca CMO 1993. Ideologia e políticas públicas: a construção da nação e a reforma do Ministério da Educação e Saúde Pública (1934-1937). Casa de Oswaldo Cruz, Fiocruz, Rio de Janeiro. (Digit.)

Franco O 1969. História da febre amarela no Brasil. MS/ DNERu, Rio de Janeiro.

Lima NT e Britto N 1996. Salud y nación: propuesta para el saneamento rural. Un estúdio de la revista Saúde (1918-1919), pp. 135-158. In Cueto M (ed.), Salud, cultura y sociedad en América Latina: nuevas perspectivas históricas. IEP-OPS, Lima.

Lima NT e Hochman G 1996. Condenado pela raça, absolvido pela medicina: o Brasil descoberto pelo movimento sanitarista da Primeira República, pp. 23 40. In Chor M e Santos R (eds.), Raça, ciência e sociedade. FCBB-Editora Fiocruz, Rio de Janeiro.

Löwy I 1999. Representação e intervenção em saúde pública: vírus, mosquitos e especialistas da Fundação Rockefeller no Brasil. In História, ciências, saúde: Manguinhos. Vol.V, no 3,(nov. 1998-fev. 1999), Casa de Oswaldo Cruz, Fiocruz, Rio de Janeiro. 